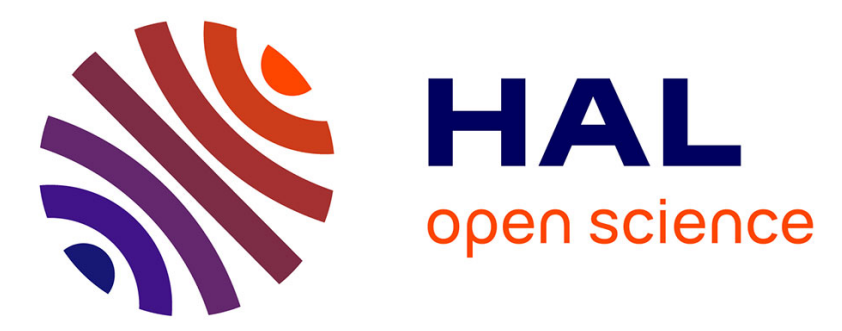

\title{
Early Paleozoic tectonic evolution of the Xing-Meng Orogenic Belt: constraints from detrital zircon geochronology of western Erguna-Xing'an Block, North China
}

\author{
Pan Zhao, Junqin Fang, Bei Xu, Yan Chen, Michel Faure
}

\section{To cite this version:}

Pan Zhao, Junqin Fang, Bei Xu, Yan Chen, Michel Faure. Early Paleozoic tectonic evolution of the Xing-Meng Orogenic Belt: constraints from detrital zircon geochronology of western ErgunaXing'an Block, North China. Journal of Southeast Asian earth sciences, 2014, 95, pp.136-146. 10.1016/j.jseaes.2014.04.011 . insu-00994407

\section{HAL Id: insu-00994407 https://hal-insu.archives-ouvertes.fr/insu-00994407}

Submitted on 2 Jul 2014

HAL is a multi-disciplinary open access archive for the deposit and dissemination of scientific research documents, whether they are published or not. The documents may come from teaching and research institutions in France or abroad, or from public or private research centers.
L'archive ouverte pluridisciplinaire HAL, est destinée au dépôt et à la diffusion de documents scientifiques de niveau recherche, publiés ou non, émanant des établissements d'enseignement et de recherche français ou étrangers, des laboratoires publics ou privés. 
Early Paleozoic tectonic evolution of the Xing-Meng Orogenic Belt: constraints from detrital zircon geochronology of western Erguna-Xing'an Block, North China

Zhao Pan ${ }^{\mathrm{a}, \mathrm{b}, \mathrm{c}, \mathrm{d}}$, Fang Junqin ${ }^{\mathrm{a}}, \mathrm{Xu} \mathrm{Be}^{\mathrm{a}^{\mathrm{a}}}$, Chen Yan $^{\mathrm{b}, \mathrm{c}, \mathrm{d}}$, Faure Michel ${ }^{\mathrm{b}, \mathrm{c}, \mathrm{d}}$

${ }^{a}$ Key Laboratory of Orogenic Belts and Crustal Evolution, Ministry of Education, Peking University, Beijing, 100871, China

bUniversité d'Orléans, ISTO, UMR 7327, 45071 Orléans, France

${ }^{\mathrm{c} C N R S / I N S U, ~ I S T O, ~ U M R ~ 7327, ~} 45071$ Orléans, France

${ }^{\mathrm{d} B R G M}$, ISTO, UMR 7327, BP 36009, 45060 Orléans, France

*Corresponding author E-mail address: bxu@pku.edu.cn

\section{Abstract}

To better constrain the Early Paleozoic tectonic evolution of the southwestern Arigin Sum-Xilinhot-Xing'an Block, we applied detrital zircon U-Pb dating on the Ordovician to Devonian sedimentary strata along the southeastern China-Mongolia border. Most of the zircons from all five sedimentary samples display fine-scale oscillatory growth zoning and $\mathrm{Th} / \mathrm{U}$ ratios higher than 0.1 , indicating a magmatic origin. All these five Ordovician-Devonian samples display the similar age distribution patterns with age groups at $\sim 40 \mathrm{Ma}, \sim 510 \mathrm{Ma}, \sim 800 \mathrm{Ma}, \sim 950 \mathrm{Ma}$, with some Meso- to Paleo-proterozoic and Neoarchean grains. This age distribution pattern is similar to those from adjacent blocks in the southeastern Central Asian Orogenic Belt. Taking previous tectonic studies into consideration, bidirectional provenances 
from the Erguna-Xing'an Block and Baolidao Arc were suggested.

Consequently, a new model was proposed to highlight the Early Paleozoic tectonic evolution of the southern margin of Arigin Sum-Xilinhot-Xing'an Block. The collision between Erguna-Kerulen Block and Arigin Sum-Xilinhot-Xing'an Block occurred before the Late Cambrian, with Late Cambrian granitic and mafic intrusions along both sides of the suture zone. After that, sedimentary basins developed in the Erguna-Xing'an Block during the Ordovician-Silurian accompanying with coeval magmatic intrusions, which provided provenance for sedimentary basins together with the Late Cambrian intrusions. Meanwhile, the northward subduction of the Paleo-Asian Ocean beneath the Arigin Sum-Xilinhot-Xing'an Block was from $~ 490$ Ma to $420 \mathrm{Ma}$, producing the Baolidao Arc magmatism along its southern margin, which also made contribution for the provenance. The eastward successive closure of marine sedimentary basins on the Arigin Sum-Xilinhot-Xing'an Block took place at the Early Devonian to the west and Late Devonian to the east, due to the pre-Late Devonian collision between the Songliao-Hunshandake Block and the Arigin Sum-Xilinhot-Xing'an Block.

Key words: Xing-Meng Orogenic Belt, Early Paleozoic, detrital zircon, Erguna-Xing'an Block, Inner Mongolia

\section{Introduction}

The Xing-Meng Orogenic Belt (XMOB), located to the southeast of Central Asian Orogenic Belt (CAOB; Fig. 1a), recorded the accretionary history among 
several main blocks, such as North China Craton (NCC), Songliao-Hunshandake Block (SHB), Airgin Sum-Xilinhot-Xing'an Block (AXXB) and Erguna Block (EB)(Fig. 1a; Wu et al., 2007; Zhou et al., 2011). These blocks experienced multi-stage of amalgamation during the Paleozoic. Numerous studies have been carried out in the past two decades, however, no consensus about the tectonic evolution of XMOB could have been reached (e.g. Xiao et al., 2003; Wu et al., 2011; Zhou et al., 2011; Zhang et al., 2012; Xu et al., 2013). The collision between EB and AXXB is considered to be occured before the Late Cambrian, as orogenic related Late Cambrian alkaline granites, granotoids and gabbros were identified from both sides of the Xinlin-Xiguitu suture zone, representing a post-collisional setting (Fig. 1a; Sorokin et al., 2004; 2011; Wu et al., 2005; 2007; Ge et al., 2005; Wu et al., 2011). After that, the new formed Erguna-Xing'an Block (EXB) involved into the Paleozoic accretionary process. From the Late Cambrian, the Paleo-Asian Ocean subducted beneath the AXXB to the north and the NCC to the south, with two arc magmatic belts developed (Liu et al., 2003; Jian et al., 2008; Xu et al., 2013; Zhang et al., 2013). High presure metamorphic blueschist was identified from both northern and southern belts, with ${ }^{40} \mathrm{Ar}^{39}{ }^{39} \mathrm{Ar}$ ages of $383 \pm 13 \mathrm{Ma}$ and 453-446 Ma, respectively (Xu et al., 2001; Tang and Yan, 1993; De Jong et al., 2006). By structural geology and sedimentary investigations, two unconformities were described, with the ductilely deformed Ondor Sum Group and ophiolitic mélange unconformably overlain by the Late Devonian molasse along the northern suture and the Late Silurian molasse along the southern one (Tang, 1990; Xu et al., 2013). It means that the amalgamation of 
EXB, SHB and NCC occurred before the end of Devonian, without wide ocean existing in between, which confirmed by recent paleomagnetic study (Zhao et al., 2013) and palaeontological study (Zhou et al., 2010; Xin et al., 2011). However, different arguments have been put forward to consider that the final collision occurred in the Late Permian based on the geochemistry studies on the Carboniferous-Permian magmatic rocks (Chen et al., 2000; Xiao et al., 2003; Zhang et al., 2009). Therefore, the tectonic evolution between EXB and SHB is still controversal, especially the south margin of EXB.

In this study, we carried out detrital zircon geochronological investigation on the Ordovician-Devonian strata in the northwestern part of the AXXB (Fig. 1), where investigations remain rare. Form these new data, we try to decipher the sedimentary responses to the collision between the $\mathrm{EB}$ and $\mathrm{AXXB}$, and the superposed influence of the subsequent collision between EXB and SHB.

\section{Geological setting}

The northeastern China is divided into several blocks, namely Erguna Block, Airgin Sum-Xilinhot-Xing'an Block, Songliao-Hunshandake Block and Jiamusi Block from north to south (Wu et al., 2007; Xu et al., 2013; Fig. 1a). These blocks share the similar Paleo- to Neo-Proterozoic basement, which was revealed by both geochronological studies of magmatic massifs and detrital zircon dating of metasedimentary rocks (Wang et al., 2001; Wu et al., 2011; Li et al., 2011; Han et al., 2011; Zhang et al., 2012 and references therein; Wu et al., 2012; Sun et al., 2013a; b; Tang et al., 2013). To the west, according to the new tectonic subdivision of Mongolia 
(Tomurtogoo, 2013), the Erguna Block might connect with the Kerulen Block (Erguna-Kerulen Block, EKB), the Airgin Sum-Xilinhot-Xing'an Block connected with the Totoshan Block at the southmost of Mongolia (Fig. 1a; Wang et al., 2001; Xu et al., 2013; Zhou et al., 2013). However, some researchers suspect the existence of AXXB due to the lack of precambrian basement and some Paleozoic zircons identified from geochronological studies of the Xilinhot complex (Wu et al., 2007; Xue et al., 2009; Chen et al., 2009). In the recent studies, Ge et al. (2011) isolated the late Mesoproterozoic supracrustal rocks from the Xilinhot complex, which was intruded by $\sim 740$ Ma metagabbro, indicating the existence of precambrian basement. Meanwhile, Mesoproterozoic granitic gneisses were recently reported from the east of Sunidzuoqi with zircon U-Pb age of 1516-1390 Ma, considered as the basement of AXXB (Sun et al., 2013b).

The study area located along the southeastern part of China-Mongolia border, belonging to the northwestern margin of the AXXB, which was separated from the northern EKB by the Xinlin-Xiguitu suture zone (XXS)(Fig. 1a). To the south, it was separated from Songliao-Hunshandake Block by the Suzuoqi-Xilinhot-Heihe suture zone (SXHS), which was thought to be formed during the Late Devonian-Early Carboniferous based on the Late Devonian unconformity and Carboniferous post-collisional intrusions (Fig. 1; Zhang et al., 2012; Xu et al., 2013).

The oldest strata of the study area are Ordovician in the age, consisting of Lower-Middle Ordovician Wubinaobao and Tongshan formations, Middle Ordovician Duobaoshan Formation, and Middle-Upper Ordovician Luohe Formation (Fig. 2). 
Except for the Duobaoshan Formation, which is mainly made of basaltic andesite, the other formations are mainly composed of fine-grained clastic sediments. The Silurian strata are rare in the study area, only Upper Silurian Woduhe Formation was identified from the Narenbaolige and eastern West Ujimqin area (Fig. 2), characterized by Late Silurian Tuvaella fauna bearing clsatic rocks and carbonates (Su, 1981; IMBGMR, 1991; Wang et al., 2009). The well distributed Lower-Middle Devonian Niqiuhe Formation (Fig. 1b) mainly consists of clastic rocks from conglomerate to siltstone with several limestone interlayers, and displays large differences of sedimentary facies from western to eastern part (Fig. 2). It is characterized by its abundant shallow marine fauna, such as brachiopoda, bivalve, coral and trilobita (IMBGMR, 1991). The Middle-Upper Devonian strata were mainly distributed in the west of West Ujimqin, namely Middle-Upper Devonian Tarbaget Formation and Upper Devonian Angeryinwula Formation (Fig. 2). Both of these two formations are mainly composed of fine-grained clastic rocks (Fig. 2). However, corals and brachiopoda were found in the the Tarbaget Formation, while plant fossils were identified in the Angeryinwula Formation, indicating a regression related depositional facies transition from shallow marine to continental facies (IMBGR, 2007). The Upper Carboniferous-Lower Permian Baoligaomiao/Gegenaobao Formation, a ca. 5000 m-thick sequence, unconformbly covered the underlying strata. It is composed of conglomerate, coarse sandstone and sandstone at the lower part and volcanic and volcano-clastic rocks at the upper part. The abundant flora found therein and the geochemical signatures of volcanic rocks reveal the continental deposition (IMBGMR, 1991; Li et al., 1996; 
Zhang et al., 2011). The volcanic rocks are coeval or slightly earlier than the Early Permian alkaline granite, together, they constitute an Early Permian rift-related alkaline magmatic belt (Hong et al., 1994; 1996; Jahn et al., 2009).

\section{Sampling}

Five sandstone-siltstone samples were collected from three localities for detrital zircon $\mathrm{U}-\mathrm{Pb}$ dating. The detailed sampling information is described below.

Two samples were collected from the northwest of Chaganaobao County (Fig.

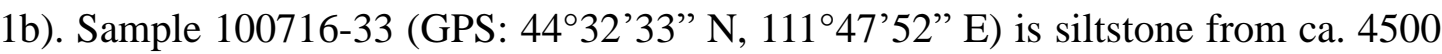
m-thick Lower-Middle Ordovician Wubinabo Formation (Fig. 2). It is mainly composed of dark green siltstone with penetrative schistosity (Fig. 3a), with grey sandstone interlayers (Fig. 2). Sample 100826-01 (GPS: 44³0’88” N, 11157’39” E) is red coarse sandstone from the Lower-Middle Devonian Niqiuhe Formation (Fig. 2). Following the underlying conglomerate (Fig. 3f), the red coarse sandstone is considered as near shore deposition with plenty of lithic grains can be observed (Fig. $3 b)$.

Two samples were collected from the northwest of Narenbaolige County (Fig.

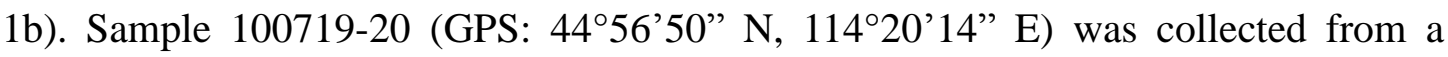
sandstone layer at the bottom of the Middle-Upper Ordovician Luohe Formation (Fig. 2). It was grayish-green in color with high propotion of basaltic lithics observed in the thin section (Fig. 3c), which might come from the underlying Duobaoshan basaltic

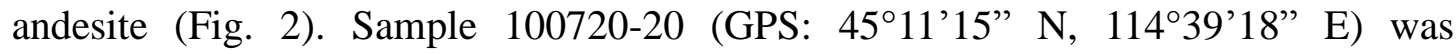
collected from the lower part of the Lower-Middle Devonian Niqiuhe Formation (Fig. 
2). This sandstone is gray in color with wave bedding and parallel bedding developed. Lithic grains, polycrystal and monocrystal quartz constitute the main clastics of this sandstone (Fig. 3d).

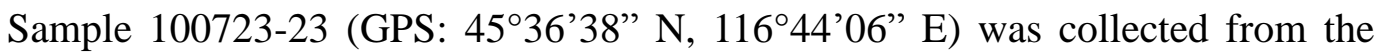
Lower-Middle Devonian Niqiuhe Formation in the northwest of West Ujimqin County (Fig. 1b). It is yellowish fine-grained sandstone with trilobita and brachiopoda fossils found nearby, indicating stable sedimentation and long distance transportation of provenance (Fig. 3e).

\section{Analytical procedures}

Zircons were separated using conventional heavy liquid and magnetic techniques before handpicking under a binocular microscope at the Langfang Regional Geogogical Survey, Hebei Province, China. Handpicked zircons were photographed under transmitted and reflected light under optical microscope before cathodoluminescence (CL) imaging using a Quanta 200 FEG Scanning Electron Microscope in Peking University in order to investigate the internal textures and choose potential target sites for U-Pb analyses. Zircon $\mathrm{U}-\mathrm{Pb}$ dating was carried out using an Agilient 7500c ICP-MS instrument coupled with a 193-nm ArF Excimer laser with the automatic positioning system at the Key Laboratory of Orogen and Crust Evolution, Peking University. Calibrations for zircon analyses were carried out using NIST 610 glass as an external standard and Si as internal standard. U-Pb isotope fractionation effects were corrected using zircon Plesovice (337 Ma) as external standard. Zircon standard 91500 is used as a secondary standard to supervise the 
deviation of age measurement/calculation. Isotopic ratios and element concentrations of zircons were calculated using GLITTER (ver. 4.4.2, Macquarie University). Concordia ages and diagrams were obtained using Isoplot/Ex (3.0) (Ludwig, 2003). The common lead was corrected using LA-ICP-MS Common Lead Correction (ver. 3.15), followed the method of Andersen (2002). The analytical data are presented on U-Pb Concordia diagrams with 2 s with 23.15 ), followed were weighted means at $95 \%$ confidence levels (Ludwig, 2003).

5. U-Pb zircon dating results

\subsection{Chaganaobao area}

\subsubsection{Lower-Middle Ordovician siltstone (Sample 100716-33)}

The zircon grains are euhedral to subhedral, ranging from $30-50 \mu \mathrm{m}$ in width and 50 to $100 \mu \mathrm{m}$ in length with fine-scale oscillatory growth zoning (Fig. 4a). The Th/U ratios range from 0.12 to 1.44 , indicating magmatic origin (e.g. Rubatto, 2002; Corfu et al., 2003). A total of 75 zircons were analyzed and 12 of them were discarded because of high discordance(Supplementary Table 1). The 63 concordant analyses yield apparent ages ranging from $440 \pm 6 \mathrm{Ma}$ to $2534 \pm 12 \mathrm{Ma}$ and fall into three main age populations: $440-577 \mathrm{Ma}(\mathrm{n}=30)$ with a peak at $491 \mathrm{Ma}, 766-956 \mathrm{Ma}(\mathrm{n}=25)$ with peaks at 827 and $950 \mathrm{Ma}, 1019-1598 \mathrm{Ma}(\mathrm{n}=5)$ without peak age, respectively (Figs. 5a and 5b). In addition, one grain yielded an age of $697 \pm 8 \mathrm{Ma}$ and two grains yielded Archean ages of $2530 \pm 12$ and $2534 \pm 12 \mathrm{Ma}$ (Supplementary Table 1).

\subsubsection{Lower-Middle Devonian Coarse Sandstone (Sample 100826-01)}

The zircon grains are euhedral to subhedral, ranging from $50-150 \mu \mathrm{m}$ in width 
and 100 to $250 \mu \mathrm{m}$ in length with well developed oscillatory growth zoning (Fig. 4b). The majority of zircons display high $\mathrm{Th} / \mathrm{U}$ ratios ranging from 0.24 to 1.06 , indicative of magmatic origin. However, 7 grains show $\mathrm{Th} / \mathrm{U}$ ratios less than $0.1(0.08-0.09)$, which may indicate their metamorphic origin (Rubatto, 2002). All of 75 analyses are concordant, ranging from $449 \pm 7$ to $923 \pm 16$ Ma. Two main age populations are defined at 487-527 Ma $(\mathrm{n}=40)$ with a peak at $508 \mathrm{Ma}$, and 536-608 Ma $(\mathrm{n}=30)$ with a peak at $576 \mathrm{Ma}$ (Figs. 5c and 5d). Meanwhile, five zircons yielded ungrouped ages of 449, 678, 794, 892 and 923 Ma (Supplementary Table 1; Figs. 5c and 5d).

\subsection{Baiyintuga area}

\subsubsection{Middle-Upper Ordovician Siltstone (Sample 100719-20)}

The majority of zircon grains are subhedral to subrounded, ranging from 30 to $100 \mu \mathrm{m}$ in width and 60-200 $\mu \mathrm{m}$ in length (Fig. 4c). Most zircon grains display oscillatory growth zoning, with a few showing inherited cores and rims (Fig. 4c). All zircons except one (0.03 for \#1920-01 with an age of $2081 \pm 19 \mathrm{Ma}$ ) give high $\mathrm{Th} / \mathrm{U}$ ratios from 0.24 to 1.47 , indicating magmatic origin. Amonga totalof 75 analyses, 69 concordant analyses yielded ages ranging from $428 \pm 6 \mathrm{Ma}$ Ma to $2092 \pm 17$ (Supplementary Table 1; Figs. 5e and 5f), and fell into one main age population at 428-547 Ma (n=63), with two peaks at 442 Ma and 511 Ma (Figs. 5e and 5f). Meanwhile, six zircons yielded ungrouped ages of 753, 940, 1282, 1461, 2081 and 2092 Ma.

\subsubsection{Lower-Middle Devonian Sandstone (Sample 100720-20)}

Most of zircon grains are subhedral to subrounded, ranging from 40 to $80 \mu \mathrm{m}$ in 
width and 50-200 $\mu \mathrm{m}$ in length (Fig. 4d). Most zircon grains display oscillatory growth zoning, while a small proportion shows inherited cores and rims (Fig. 4d). Except two grains with $\mathrm{Th} / \mathrm{U}$ ratio less than 0.1 , all other zircons show high $\mathrm{Th} / \mathrm{U}$ ratios from 0.11 to 1.09 , indicating magmatic origin. Among a total of $75 \mathrm{U}-\mathrm{Pb}$ analyses, 67 of them are concordant and yielded ages ranging from $453 \pm 6$ Ma to $2227 \pm 14 \mathrm{Ma}$ (Supplementary Table 1; Figs. $5 \mathrm{~g}$ and $5 \mathrm{~h}$ ). The grains fall into two main age populations at $453-581 \mathrm{Ma}(\mathrm{n}=49)$ with two peaks at $459 \mathrm{Ma}$ and $512 \mathrm{Ma}$, and 669-917 Ma (n=17) with peak at $794 \mathrm{Ma}$ (Figs. 5g and 5h). In addition, one grain yielded ages of $2227 \pm 14$ Ma.

5.3 West Ujimqin Lower-Middle Devonian Sandstone (Sample 100723-23)

The zircon grains are euhedral to subhedral, ranging from 50-100 $\mu \mathrm{m}$ in width and 80 to $150 \mu \mathrm{m}$ in length with oscillatory growth zoning (Fig. 4e). Except one grain showing $\mathrm{Th} / \mathrm{U}$ ratio of 0.04 , all other zircons show high $\mathrm{Th} / \mathrm{U}$ ratios from 0.13 to 0.91 , indicating magmatic origin. Among a total of 74 analyses, 8 analyses were discarded because of high discordance, and one grain (\#2325-20 with age of 214 \pm 3 ) was also discarded (Supplementary Table 1). The 65 concordant analyses yielded ages ranging from $394 \pm 6$ Ma to $2018 \pm 45$ Ma (Supplementary Table 1; Figs. 5i and 5j). Broadly, the grains fall into three age populations at $394-495 \mathrm{Ma}(\mathrm{n}=37)$ with a peak at $435 \mathrm{Ma}$, 505-546 Ma $(\mathrm{n}=15)$ with peak at $511 \mathrm{Ma}$, and 778-1078 Ma $(\mathrm{n}=11)$ with a small peak at 959 Ma, respectively (Fig. 5j). Meanwhile, two zircon yielded ages of 624 and 2018 Ma (Supplementary Table 1; Figs. 7i and 7j).

6. Discussion 
6.1. Constraint on the depositional age of studied Ordovician-Devonian strata

The depositional ages of the investigated Ordovician to Devonian formations were determined using association of fossils and regional lithology correlation. Due to the poorly preserved fossils (especially for Ordovician strata) and lithological variations from region to region, the stratigraphic division of the OrdovicianDevonian stratain this area is not precise. Our detrital zircon data provide new constraint for their age assignment.

The youngest zircon age of the Lower-Middle Ordovician Wubinaobao Formation siltstone is $440 \pm 6 \mathrm{Ma}$, but, defined by just one grain. Consequently, we use here the youngest grouped zircon age of $461 \pm 6$ Ma defind by 14 grains (Supplementary Table 1) to constrain the depositional age of the Wubinaobao Formation. This age drops into the Middle Ordovician, and is therefore consistent with the former fossil constraint (IMBGMR, 1991). For the Middle-Upper Ordovician Luohe Formation, the youngest grouped zircon age is $428 \pm 6 \mathrm{Ma}$, constraining the depositional age to be younger than the Early Silurian, and is slightly younger than the previous assignment (IMBGMR, 1991). The abundant fossils found within the Niqiuhe Formation have well constrained its Early-Middle Devonian age, and our

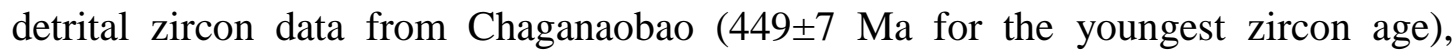
Baiyintuga(453 \pm 6 Ma for the youngest zircon age) and West Ujimqin (394 \pm 6 Ma for the youngest zircon age) are consistent with this age assignment. So, the depositional age of the Niqiuhe Formation should be of the Early-Middle Devonian.

6.2 Provenance of Ordovician and Devonian strata 
The detrital zircon dating results presented above give us new clue to trace the provenance of these sediments and decipher the tectonic evolution. All these five Ordovician-Devonian samples display similar distributions in zircon age probability diagrams, characterized by predominant Early Paleozoic age groups at $440 \mathrm{Ma}$ and $\sim 510 \mathrm{Ma}$, and subordinate Neoproterozoic age groups at $\sim 570 \mathrm{Ma}, \sim 800 \mathrm{Ma}$ and $\sim 950$ Ma, respectively, with only few grains of pre-1.0 Ga (Figs. 5 and 6a). It indicates relatively stable provenance for this belt from the Ordovician to the Devonian.

The most striking feature of zircon age distribution for this study is the predominant peak age at $\sim 510 \mathrm{Ma}$ (Fig. 6a). This significant age group was well documented from the EKB (Wu et al., 2005; 2012) and AXXB (Figs. 6b and 6c; Li et al., 2010; Han et al., 2011) by geochronological studies of granotoids and clastic rocks, which was considered as the orogenic related magmatic event related to the collision between the EKB and AXXB (Wu et al., 2005). Furthermore, this age group has also been revealed by zircon studies of igneous rocks from northwestern-central Mongolia (Fig. 6d; Rojas-Agramonte et al., 2011), central Mongolia (Demoux et al., 2009a), and southern Mongolia (Demoux et al., 2009b). Most of the 510 Ma zircons display $\mathrm{Th} / \mathrm{U}$ ratios higher than 0.1 (Supplementary Table 1), which implies that these zircon grains came from the Cambrian magmatic rocks exposed on the EKB, AXXB or/and the Mongolian blocks. Moreover, we noticed that 4 zircons from Sample 100826-01 and 1 zircon from Sample 100723-23 present Th/U ratios less than 0.1 and $\mathrm{U}-\mathrm{Pb}$ age of 497-517 Ma (Supplementary Table 1), showing the same feature with zircons from Pan-African events in the northeastern margin of the EKB and AXXB (Zhou et al., 
2011; Zhou and Wilde, 2013).

The age peak of $\sim 440$ Ma may represent the regional Early Paleozoic magmatic event. Two Early Paleozoic magmatic events have been documented from nearby blocks. After the agglomeration of the EKB and AXXB at the Cambrian, the Early Paleozoic post-collisional magmatic intrusions from $\sim 490$ to $\sim 440$ Ma were taken place on the newly formed EXB (Wu et al., 2005; Ge et al., 2005; Sorokin et al., 2011; Ren et al., 2012; Guo et al., 2013). To the south, the Early Paleozoic Baolidao arc magmatism at the southern margin of the AXXB was dated at 498-415 Ma (Jian et al., 2008; Xu et al., 2013). These two kinds of magmatic rocks can both be considered as provenance regions for this zircon group. Notably, only one zircon from the western Chaganaobao Devonian sample (100826-01) presents an age around this age peak, with the main age group at $508 \mathrm{Ma}$ (Fig. 6b), indicating the main provenance for the Devonian strata here is the EXB. However, the percentage of the Early Paleozoic zircon grains increases eastwards (Figs. 6b, 6d and 6e). The easternmost Devonian sample from West Ujimqin (100723-23) presents the main age peak at $435 \mathrm{Ma}$, which is most probably from the southern Baolidao magmatic arc. This eastward tendancy indicates that the contribution of the Baolidao arc to the provenance of Devonian strata increases from west to east.

The Neoproterozoic peaks (800-1000 Ma) are subordinate in our results (Fig. 5), and they can't be used as an effective provenance indicator because this peak age represents the universal basement of nearly all blocks between NCC and Siberia Block (SIB). Neoproterozoic alkaline plutons have been identified from the EKB with 
the age of 950-737 Ma (Wu et al., 2011; Tang et al., 2013), which represent an extensive environment (Tang et al., 2013). For the eastern Jiamusi Block, genisess and granitoids with the age of 913-777 Ma were reported at its western margin (Xie et al., 2008). This Neoproterozoic basement was also identified from the SHB by detrital zircon dating of Late Neoproterozoic-Cambrian metasedimentary rocks (Xu et al., 2013; Wang et al., 2013). For the AXXB, ca. 900 Ma gensiss were reported along the China-Mongolia border (Wang et al., 2001; Zhou et al., 2013). The ca. $950 \mathrm{Ma}$ magmatic events were also recorded in the central and southern Mongolia (Kröner et al., 2007; Demoux et al., 2009b). To the northern Tuva-Mongolia Block, a magmatism of the same age was also reported along the southern margin of SIB (Kuzmichev et al., 2001; Gladkochub et al., 2007). These universal Neoproterozoic magmatic rocks in these blocks correspond to an important global magmatic event, which may be related to the assemblage and break-up of Rodinia supercontinent (Li et al., 2008).

In summary, the presented results above indicate bidirectional provenances from the EXB, and the Early Paleozoic Baolidao arc to the south for the Ordovician-Devonian deposition. It provides new clue to decipher the tectonic evolution of this region.

\subsection{Tectonic implications}

A new model was proposed based on our new geochological data to interpreate the Early Paleozoic tectonic evolution of the AXXB with its neighbor blocks.

The collision between EKB and AXXB occurred before the Late Cambrian, followed by Late Cambrian granitic and mafic intrusions (Wu et al., 2005; Ge et al., 
2005; Wu et al., 2011) on both side of Xinlin-Xiguitu suture zone (Fig. 7a). During this period, the southern margin of this new formed block was an passive continental margin, and separated from the southern SHB by the Paleo-Asian Ocean (Fig. 7a).

After that, the new welded Erguna-Xing'an Block (EXB) came into a epicontinental setting, with Ordovician-Silurian sedimentary basin developed accompanied with coeval magmatic intrusions (Fig. 7b; IMBGMR, 1991; Ge et al., 2007; Sorokin et al., 2004; 2011; Ren et al., 2012; Guo et al., 2013). The Cambrian (510-485 Ma) orogenic related granitic and mafic intrusions and subsequent Ordovician-Silurian (485-440 Ma) magmatic intrusions provide provenance for the basin deposition (Fig. 7b). Ever since the Paleo-Asian Ocean subducted beneath the southern margin of the welded EXB, the Baolidao arc formed along this margin from $\sim 490 \mathrm{Ma}$ to $\sim 420 \mathrm{Ma}$, with the peak at $\sim 460 \mathrm{Ma}$ (Shi et al., 2005; Jian et al., 2008; $\mathrm{Xu}$ et al., 2013). The Baolidao arc granitoids intruded into the Xilinhot precambrian basement, and extensive thermal metamorphism related to the arc magmatism occurred in the precambian basement (Sun et al., 2013b), which also made contribution for the provenance of the basin deposition (Fig. 7).

During the Late Silurian, the magmatic events on the EXB have ceased, and it was dominated by the widespread clastic and carbonate deposits without volcanic component (Fig. 2). The striking feature of these Upper Silurian strata is the Tuvaella funa therein, which can be traced from nearly all the Upper Silurian strata from the EXB (Su et al., 1981; IMBGMR, 1991), marking the stablization of this new formed block (Fig. 7c; Wang et al., 2009). To the south, the subduction of the Paleo-Asian 
Ocean was still going, but the Baolidao Arc magmatism ceased at the Late Silurian (Fig. 7c), represented by $~ 420$ Ma high-K granite (Shi et al., 2005; Jian et al., 2008). During the Early-Middle Devonian, the marine sedimentary basins on the EXB show significant lateral lithological variations from west to east (Fig. 2). At the Chaganaobao area, the distinctive red basal conglomerate (Figs. $3 \mathrm{f}$ and 7) represents a regional unconformity, indicating that the sedimentary basin might have been closed before the Early Devonian in this area. However, to the east, the Early-Middle Devonian strata are mainly composed of shallow marine sandstone with abundant of shallow marine fossils, indicating that the marine sedimentary basins still exist. These variations indicate an Early-Middle Devonian eastaward regression, revealing an eastward successive closure of the marine basin (Fig. 7d). During the Late Devonian, due to the collision between the SHB and the EXB, the Late Devonian molassic deposition uncomformbly overlied the ophiolitic melange (Xu et al., 2013; Fig. 7d). This collision also caused the final closure of the marine sedimentary basins on the EXB, as no Late Devonian sediments were found to the west and the plant fossils bearing continental Upper Devonian Angeryinwula Formation occurred to the east (West Ujimqin area) (IMBGR, 2007; Fig. 7d). After the Late Devonian the EXB came into a subaerial setting without sedimentation until the Late Carboniferous continental deposition (IMBGMR, 1991).

\section{Conclusions}

(1) The detrital zircon geochronological study of the five Ordovician-Devonian samples from Erenhot-West Ujimqin (the southeastern part of the China-Mongolia 
border) display the similar age distribution patterns with age groups at $\sim 440 \mathrm{Ma}, \sim 510$ Ma, $800 \mathrm{Ma}, \sim 950 \mathrm{Ma}$, some Meso- to Paleo-proterozoic and Neoarchean grains.

(2) This age distribution display the same patterns with the magmatic periods of Erguna-Xing'an Block. Meanwhile, the youngest age group is well consistent with the Bolidao Arc magmatism at the southern margin of the Erguna-Xing'an Block. Hence, a bidirectional provenances from the Erguna-Xing'an Block and Baolidao Arc was proposed.

(3) All our data constrain two main Early Paleozoic tectonic events of the Xing-Meng Orogenic Belt: pre-Late Cambrian collision between Erguna-Kerulen Block and Arigin Sum-Xilinhot-Xing'an Block; the Early Paleozoic subduction of Paleo-Asian Ocean and pre-Late Devonian collision between Erguna-Xing'an Block and Songliao-Hunshandake Block.

(4) A new model was proposed to highlight this Early Paleozoic tectonic evolution. The collision between Erguna-Kerulen Block and Arigin Sum-Xilinhot-Xing'an Block occurred before the Late Cambrian, with Late Cambrian granitic and mafic intrusions along both sides of the suture zone. After that, sedimentary basins developed in the Erguna-Xing'an Block during the Ordovician-Silurian accompanying with coeval magmatic intrusions, which provided provenance for sedimentary basins together with the Late Cambrian intrusions. Meanwhile, the northward subduction of the Paleo-Asian Ocean beneath the Arigin Sum-Xilinhot-Xing'an Block was from 490 Ma to 420 Ma, producing the Baolidao Arc magmatism along its southern margin, which also made contribution for the 
provenance. The eastward successive closure of marine sedimentary basins on the Arigin Sum-Xilinhot-Xing'an Block took place at the Early Devonian to the west and Late Devonian to the east, due to the pre-Late Devonian collision between the Songliao-Hunshandake Block and the Arigin Sum-Xilinhot-Xing'an Block.

\section{Acknowledgments}

We thank Shi Guanzhong and Li Ruibiao for their support in the field. This work has been funded by the National Key Basic Research Program of China (2013CB429800), the National Science Foundation of China (40872145 and 41121062), and the China Geological Survey Grant (no. 1212011220906).

\section{Reference}

Andersen, T. 2002. Correction of common lead in $\mathrm{U}-\mathrm{Pb}$ analyses that do not report ${ }^{204} \mathrm{~Pb}$, Chemical Geology, 192, 59-79.

Badarch, G., Cunningham, W.D., Windley, B.F., 2002. A new terranne subdivision for Mongolia: implications for the Phanerozoic crustal grouth of Central Asia. Journal of Asian Earth Science 21, 87-100.

Chen, B., Jahn, B.M., Wilde, S., Xu, B. 2000. Two contrasting Paleozoic magmatic belts in northern Inner Mongolia, China: petrogenesis and tectonic implications. Tectonophysics 328, 157-182.

Chen, B., Ma, X.H., Liu, A.K., Muhetaer, Z., 2009. Zircon U-Pb ages of the Xilinhot Metamorphic complex and blueschist, and implications for tectonic evolution of 
the Solonker suture. Acta Petrologica Sinica 25 (12), 3123-3129 (in Chinese with English abstract).

Corfu, F., Hanchar, J.M., Hoskin, P.W.O., Kinny, P.D., 2003. Atlas of zircon textures. Reviews in Mineralogy and Geochemistry 53, 469-500.

De Jong, K., Xiao, W.J., Windley, B.F., Masago, H., Lo, C.H., 2006. Ordovician ${ }^{40} \mathrm{Ar} /{ }^{39} \mathrm{Ar}$ phengite ages from the blueschist-facies Ondor Sum subductionaccretion complex (Inner Mongolia) and implications for the Early Paleozoic history of continental blocks in China and adjacent areas. American Journal of Science 306, 799-845.

Demoux, A., Kröner, A., Badarch, G.T., Jian, P., Tomurhuu, D., Wingate, M.T.D., 2009a. Zircon ages from the Baydrag Block and the Bayankhongor ophiolite zone: time constraints on late Neoproterozoic to Cambrian subduction- and accretion-related magmatism in Central Mongolia. Journal of Geology 117, 377397.

Demoux, A., Kröner, A., Liu, D., Badarch, G., 2009b. Precambrian crystalline basement in southern Mongolia as revealed by SHRIMP zircon dating. International Journal of Earth Sciences 98, 1365-1380.

Ge, M., Zhou, W., Yu, Y., Sun, J., Bao, J., Wang, S., 2011. Dissolution and supracrustal rocks dating of Xilin Gol Complex, Inner Mongolia, China. Earth Science Frontiers 18(5), 182-195 (in Chinese with English abstract).

Ge, W.C., Sui, Z.M., Wu, F.Y., Zhang, J.H., Xu, X.C., Cheng, R.Y., 2007. Zircon $\mathrm{U}-\mathrm{Pb}$ ages, $\mathrm{Hf}$ isotopic characteristics and their implications of the Early 
Paleozoic granites in the northeastern Da Hinggan Mts., northeastern China. Acta Petrologica Sinica, 23(2), 423-440 (in Chinese with English abstract).

Ge, W.C., Wu, F.Y., Zhou, C.Y., Rahman, A.A.A., 2005. Emplacement age of the Tahegranite and its constraints on the tectonic nature of the Ergun block in thenorthern part of the Da Hinggan Range. Chinese Science Bulletin 50, 20972105.

Gladkochub, D.P., Donskaya, T.V., Mazukabzov, A.M., Stanevich, A.M., Sklyarov, E.V., Ponomarchuk, V.A., 2007. Signature of Precambrian extension events in the southern Siberian craton. Russian Geology and Geophysics 48, 17-31.

Guo, Z., Zhang, B., Shen, X., Jia, W., Huang, X., 2013. Discussion on the Geological characthristics and Mechanism of rock formation of the Giant Phenocryst adamellite in Southeast Mongolia. Journal of Jilin University (Earth Science Edition) 43(3), 776-787 (in Chinese with English abstract).

Han, G., Liu, Y., Neubauer, F., Genser, J., Li, W., Zhao, Y., Liang, C., 2011. Origin of terranes in the eastern Central Asian Orogenic Belt, NE China: U-Pb ages ofdetrital zircons from Ordovician-Devonian sandstones, North Da Xing'an Mts. Tectonophysics 511, 109-124.

Han, G., Liu, Y., Neubauer, F., Genser, J., Li, W., Zhao, Y., Liang, C., 2011. Origin of terranes in the eastern Central Asian Orogenic Belt, NE China: U-Pb ages of detrital zircons from Ordovician-Devonian sandstones, North Da Xing'an Mts. Tectonophysics 511, 109-124.

Hong, D., Huang, H., Xiao, Y., Xu, H., Jin, M., 1994. The Permian alkaline granites in 
central Inner Mongolia and their geodynamic significance. Acta Geologica Sinica 69(3), 219-230 (in Chinese with English abstract).

Hong, D.W.,Wang, S.G.,Han, B.F., Jin,M.Y.,1996. Post-orogenic alkaline granites fromChinaand comparisonswith anorogenic alkaline granites elsewere. Journal of SE Asian Earth Sciences 13, 13-27.

IMBGMR (Inner Mongolian Bureau of Geology and Mineral Resources), 1991. Regional geology of Inner Mongolian Autonomous Region. Geological Publishing House, Beijing (in Chinese with English abstract).

IMBGR, 2007. Geological map of China, Dongwuzhumuqinqi sheet (L50C003002), scale 1:250000.

Jahn, B.M., Litvinovsky, B.A., Zanvilevich, A.N., Reichow, M., 2009. Peralkaline granitoid magmatism in the Mongolian-Transbaikalian Belt: Evolution,petrogenesis and tectonic significance. Lithos 113, 521-539.

Jian, P., Kroner, A., Windley, B.F., Shi, Y., Zhang, W., Zhang, L., Yang, W., 2012. Carboniferous and Cretaceous mafic-ultramafic massifs in Inner Mongolia (China): A SHRIMP zircon and geochemical study of the previously presumed integral "Hegenshan ophiolite". Lithos 142-143, 48-66.

Jian, P., Liu, D., Kröner, A., Windley, B.F., Shi, Y., Zhanf, F., Shi, G., Miao, L., Zhang, W., Zhang, Q., Zhang, L., Ren, J., 2008. Time scale of an early to mid-Paleozoic orogenic cycle of the long-lived Central Asian Orogenic Belt, Inner Mongolia of China: implications for continental growth. Lithos 101, 233259. 
Kotov, A.B., Kozakov, I.K., Bibikova, E.V., 1995. Duration of regional metamorphic episodes in areas of polycyclic endogenic processes: a U-Pb geochronological study. Journal of Petrology 3, 567-575.

Kozakov, I.K., Kotov, A.B., Salnikova, E.B., Kovach, V.P., Nutman, A.P., Bibikova, T.I., Kirnozova, T.I., Todt, W., Kröner, A., Yakovleva, S.Z., Lebedev, V.I., Sugorakova, A.M., 2001. Timing of the structure evolution of metamorphic rocks in the Tuva-Mongolian Massif. Geotectonics 35, 165-184.

Kröner, A., Windley, B.F., Badarch, G., Tomurtogoo, O., Hegner, E., Jahn, B.M., Gruschka, S., Khain, E.V., Demoux, A., Wingate, M.T.D., 2007. Accretionary growth and crust-formation in the Central Asian Orogenic Belt and comparison with the Arabian-Nubian shield. Geological Society of America, Memoirs 200, 181-209.

Kuzmichev, A.B., Bibikova, E.V., Zhuravlev, D.Z., 2001. Neoproterozoic ( $>00$ Ma) orogeny in the Tuva-Mongolia Massif (Siberia): island arc-continent collision at the northeast Rodinia margin. Precambrian Research 110, 109-126.

Li, C.D., Ran, H., Zhao, L.G., Wang, H.C., Zhang, K., Xu, Y.W., Gu, YC., Zhang, Y.Q., 2012. LA-ICP-MS U-Pb geochronology of zircons from the Wenduermiao Group and its tectonic significance. Acta Petrologica Sinica 28(11), 3705-3714.

Li, D.P., Chen, Y.L., Wang, Z., Hou, K.J., Liu, C.Z., 2011. Detrital zircon U-Pb ages, Hf isotopesand tectonic implications for Palaeozoic sedimentary rocks from the Xing-Meng orogenic belt, middle-east part of inner Mongolia, China. Geological Journal 46, 63-81. 
Li, W.G., Li, Q.F., Jiang, W.D., 1996. Lithostratigraphy of Inner Mongolia Autonomous Region. Chinese University of Geoscience Press, Beijing. pp. 1-344 (in Chinese).

Li, Y., Wang, Y., Wu, G., Jin, Z., Zhang, D., Yang, X., 2013. The provenance characteristics of Tongshan Formation in north Zalantun area of the Da Hinggan Mountains: The constraint of geochemisty and LA-MC-ICPMS U-Pb dating of detrital zircons. Geology in China 40(2), 391-402 (in Chinese with English abstract).

Li, Z.X., Bogdanova, S.V., Collins, A.S.,Davidson, A.,DeWaele, B., Ernst, R.E., Fitzsimons, I.C.W., Fuck, R.A., Gladkochub, D.P., Jacobs, J., Karlstrom, K.E., Lu, S., Natapov, L.M., Pease, V., Pisarevsky, S.A.,Thrane, K.,Vernikovsky,V., 2008. Assembly, configuration, and break-up history of Rodinia: a synthesis. Precambrian Res. 160, 179-210.

Liu, D., Jian, P., Zhang, Q., Zhanf, F., Shi, Y., Shi, G., Zhang L., Tao, H., 2003. SHRIMP dating of adakites in the Tulingkai ophiolite, Inner Mongolia: evidence for the Eraly Paleozoic subduction. Acta Geologica Sinica 77(3), 317-326.

Ludwig, K.R., 2003. User's Manual for Isoplot 3.0: A Geochronological Toolkit for Microsoft Excel Berkeley Geochronology Center. special publication, 4, pp. 171.

Miao, L., Fan, W., Liu, D., Zhang, E., Shi, Y., Guo, F., 2008. Geochronology and geochemistry of the Hegenshan ophiolitic complex: implications for late-stage 
tectonic evolution of the Inner Mongolia-Daxinganling orogenic belt, China. Journal of Asian Earth Sciences 32, 348-370.

Mineral Resources Authority of Mongolia, 1998. Geological Map of Mongolia 1:1000000 scale. Mineral Resources Authority of Monglia, Geological Survey \&Institute of Geology and Mineral Resources, Mongolian Academy of Sciences, Ulaanbaatar.

Ren, B., Sun, L., Cheng, Y., Teng, X., Li, Y., Hao, S., 2012. Zircon U-Pb Ages, Hf isotopic Characteristics of the Yongqinglinchang-Shibazhan Granites in the Northern Da Hinggan Mountains, Northeastern China. Geological Survey and Research 35(2), 109-117 (in Chinese with English abstract).

Robinson, P.T., Zhou, M.F., Hu, X.F., Reynolds, P., Bai, W.J., Yang, J., 1999. Geochemical constraints on the origin of the Hegenshan ophiolite, Inner Mongolia, China. Journal of Asian Earth Sciences 17, 423-442.

Rojas-Agranonte, A., Kroner, A., Demoux, A., Xia, X., Wang, W., Donskaya, T., Liu, D., Sun, M., 2011. Detrital and xenocrystic zircon ages from Neoproterozoic to Palaeozoic arc terranesof Mongolia: Significance for the origin of crustal fragments in the Central Asian Orogenic Belt. Gondwana Research 19, 751-763.

Rubatto, D., 2002. Zircon trace element geochemistry: partitioning with garnet and the link between $\mathrm{U}-\mathrm{Pb}$ ages and metamorphism. Chemical Geology 184, 123-138.

Shi, Y.R., Liu, D.Y., Jian, P., Zhang, Q., Zhang, F.Q., Miao, L.C., Shi, G.H., Zhang, L.Q., Tao, H., 2005. Zircon SHRIMP dating of K-rich granites in Sonidzuoqi, 
central Inner Mongolia. Geological Bullentin of China 24(5), 424-428 (in Chinese with English abstract).

Sorokin, A. A., Kudryashov, N.M., Li, J.Y., et al. Early Paleozoic granitoids in the Eastern Margin of the Argun' Terrane, Amur area: first geochemical and geochronologic data. Petrology, 2004, 12(4): 367-376.

Sorokin, A.A., Kotov, A.B., Sal'nikova, E.B., Kudryashov, N.M., Velikoslavinskii, S.D., Yakovleva, S.Z., Fedoseenko, A.M., Plotkina, Y.V., 2011. Early Paleozoic Granitoids in the Lesser Khingan Terrane, Central Asian Foldbelt: Age, Geochemistry, and Geodynamic Interpretations. Petrology 19(6), 601-617.

Su, Y.Z., 1981. The distribution and entironment of Tuvaella fauna. Acta Palaeontologica Sinica 20(6), 567-574 (in Chinese).

Sun, L.X., Ren, B.F., Zhao, F.Q., Ji, S.P., Geng, J.Z., 2013a. Late Paleoproterozoic magmatic records in the Eerguna massif: evidences from the zircon $\mathrm{U}-\mathrm{Pb}$ dating of granitic gneisses. Geological Bulletin of China 32(2/3), 341-352 (in Chinese with English abstract).

Sun, L.X., Ren, B.F., Zhao, F.Q., Gu, Y.C., Li, Y.F., Liu, H., 2013b. Zircon U-Pb dating and Hf isotopic compositions of the Mesoporterozoic granitic gneiss in Xilinhot Block, Inner Mongolia. Geological Bulletin of China 32(2/3), 327-340 (in Chinese with English abstract).

Tang, J., Xu, W.L., Wang, F., Wang, W., Xu, M.J., Zhang, Y.H., 2013. Geochronology and geochemistry of Neoproterozoic magmatism in the Erguna Massif, NE China: Petrogenesis and implications for the breakup of the Rodinia 
supercontinent. Precambrian Research 224, 597-611.

Tang,K.D., 1990. Tectonic development of Paleozoic fold belts at the north margin of the Sino-Korean craton. Tectonics 9, 249-260.

Tang, K., and Yan, Z., 1993. Regional metamorphism and tectonic evolution of the Inner Mongolia suture zone. J. metamorphic Geol. 11, 511-522.

Wan, Y., Liu, D., Wang, W., Song, T., Kroner, A., Dong, C., Zhou, H., Yin, X., 2011. Provenance of Meso- to Neoproterozoic cover sediments at the Ming Tombs, Beijing, North China Craton: An integrated study of $\mathrm{U}-\mathrm{Pb}$ dating and $\mathrm{Hf}$ isotopic measurement of detrital zircons and whole-rock geochemistry. Gondwana Research 20, 219-242.

Wang, C.W., Sun, Y.W., Li, N., Zhao, G.W., Ma, X.Q., 2009. Tectonic implication of the Late Paleozoic stratigraphic distribution in Northeast China and adjacent region. Science in China Series D: Earth Science 52(5), 619-626.

Wang, F., Xu, W.L., Gao, F.H., Zhang, H.H., Pei, F.P., Zhao, L., Yang, Y., 2013. Precambrian terrane within the Songnen-Zhangguangcai Range Massif, NE China: Evidence from U-Pb ages of detrital zircons from the Dongfengshan and Tadong groups. Gondwana Research, http://dx.doi.org/10.1016/j.gr.2013.06.017

Wang, T., Zheng, Y.D., Gehrels, G.E., Mu, Z.G., 2001. Geochronological evidence for existence of the south Mongolian microcontinent: a zircon $\mathrm{U}-\mathrm{Pb}$ age of granitoid gneisses from the Yagan-Onch Hayrhan metamorphic core complex on the SinoMongolian border. China Science Bulltin 46, 2005-2008.

Windley, B.F., Alexeiev, D., Xiao, W.J., Kroner, A., Badarch, G., 2007. Tectonic 
models for accretion of the Central Asian Orogenic Belt. Journal of the Geological Society, London 164, 31-47.

Wu, F.Y., Sun, D.Y., Ge, W.C., Zhang, Y.B., Grant, M.L., Wilde, S.A., Jahn, B.M., 2011. Geochronologyof the Phanerozoic granitoids in northeastern China. Journal of AsianEarth Sciences 41, 1-30.

Wu, F.Y., Zhao, G.C., Sun, D.Y., Wilde, S.A., Yang, J.H., 2007. The Hulan Group: Its role in the evolution of the Central Asian Orogenic Belt of NE China. Journal of Asian Earth Sciences 30, 542-556.

Wu, G., Chen, Y., Chen, Y., Zeng Q., 2012. Zircon U-Pb ages of the metamorphic supracrustal rocks of the Xinghuadukou Group and granitic complexes in the Argun massif of the northern Great Hinggan Range, NE China, and their tectonic implications. Journal of Asian Earth Science 49, 214-233.

Wu, G., Sun, F.Y., Zhao, C.S., Li, Z.T., Zhao, A.L., Pang, Q.B., Li, G.Y., 2005. Discovery ofthe Early Paleozoic post-collisional granites in northern margin of theErguna massif and its geological significance. Chinese Science Bulletin $50,2733-2743$.

Xiao, W.J., Windley, B.F., Hao, J., Zhai, M.G., 2003. Accretion leading to collision and the Permian Solonker suture, Inner Mongolia, China: termination of the Central Asian Orogenic Belt. Tectonics 22, 1069-1089.

Xie, H.Q., Zhang, F.Q., Miao, L.C., Chen, F.K., Liu, D.Y., 2008. Zircon SHRIMP $\mathrm{U}-\mathrm{Pb}$ dating of the amphibolite from "Heilongjiang Group" and the granite in Mudanjiang area, NE China, and its geological significance. Acta Prtrologica 
Sinica 24(6), 1237-1250 (in Chinese with English abstract).

Xin, H., Teng, X., Cheng, Y., 2011. Stratigraphic Subdivision and Isotope Geochronology Study on the Baoligaomiao Formation in the East Ujimqin County, Inner Mongolia. Geological survey and Research 34(1), 1-9.

Xu, B., Charvet, J., Zhang, F.Q., 2001. Primary study on petrology and geochronology of the blueschist in Sonid Zuoqi, northern Inner Mongolia. Chinese Journal of Geology 36, 424-434 (in Chinese with English abstract).

Xu, B., Charvet, J., Chen, Y., Zhao, P., Shi, G.Z., 2013. Middle Paleozoic convergent orogenic belts in western Inner Mongolia (China): framework, kinematics, geochronology and implications for tectonic evolution of the Central Asian Orogenic Belt. Gondwana Research 23, 1324-1364.

Xue, H.M., Gou, L.J., Hou, Z.Q., Zhou, X.W., Tong, Y., Pan, X.F., 2009. The Xilingele complex from the eastern part of the Central Asian-Mongolia Orogenic Belt, China: Products of Early Variscan orogeny other than ancient block: Evidence from zircon SHRIMP U-Pb ages. Acta Pertologica Sinica 25(8), 2001-2010 (in Chinese with English abstract).

Zhang, S. H., Zhao, Y., Song, B., Hu, J. M., Liu, S. W., Yang, Y. H., Chen, F. K., Liu, X. M., Liu, J., 2009. Contrasting late Carboniferous and late Permian-middle Triassic intrusive suites from the northern margin of the north China craton. Geological Society of America Bulletin 121, 181-200.

Zhang, W., Jian, P., Kroner, A., Shi, Y., 2013. Magmatic and metamorphic development of an early to mid-Paleozoic continental margin arc in the 
southernmost Central Asian Orogenic Belt, Inner Mongolia, China. Journal of Asian Earth Science 72, 63-74.

Zhang, X., Ma, Y., Chi, X., Zhang, F., Sun, Y., Guo, Y., Zeng, Z., 2012. Discussion on Phanerozoic tectonic evolution in Northeastern China. Journal of Jilin University (Earth Science Edition) 42(5), 1269-1285 (in Chinese with English abstract).

Zhang, X., Wilde, S.A., Zhang, H., Zhai, M., 2011. Early Permian high-K calc-alkaline volcanic rocks from NW Inner Mongolia,North China: geochemistry, origin and tectonic implications. Journal of the Geological Society, London 168,525-543.

Zhang, X., Wilde, S.A., Zhang, H., Zhai, M., 2011. Early Permian high-K calc-alkaline volcanic rocks from NW Inner Mongolia, North China: geochemistry, origin and tectonic implications. Journal of the Geological Society, London 168, 525-543. doi: 10.1144/0016-76492010-094.

Zhang, X.Z., Ma, Y.X., Chi, X.G., Zhang, F.X., Sun, Y.W., Guo, Y., Zeng, Z., 2012. Discussion on Phanerozoic Tectonic Evolution in Northeastern China. Journal of Jilin University (Earth Science Edition) 42(5), 1269-1285 (in Chinese with English Abstract).

Zhao, P., Chen, Y., Xu, B., Faure, M., Shi, G., Choulet, F., 2013. Did the Paleo-AsianOcean betweenNorth China Block and Mongolia Block exist during the late Paleozoic? First paleomagnetic evidence from central-eastern Inner Mongolia, China. Journal of Geophysical Research: Solid Earth 118, 1873-1894.

Zhou, J.B., and Wilde, S.A., 2013. The crustal accretion history and tectonic evolution 
of the NE China segment of the Central Asian Orogenic Belt. Gondwana Research 23, 1365-1377.

Zhou, J.B., Wilde, S.A., Zhang, X.Z., Ren, S.M., Zheng, C.Q., 2011. Early Paleozoic metamorphic rocks of the Erguna block in the Great Xing'an Range, NE China: Evidence for the timing of magmatic and metamorphic events and their tectonic implications. Tectonophysics 499, 105-117.

Zhou Y Z, Han B F, Xu Z, Ren R, Su L. 2013. The age of the Proterozoic rocks in Yingba area in western Inner Mongolia: Constraints on the distribution of the South Gobi micro-continent in the Central Asian orogenic belt. Geological Bulletin of China 32(2/3), 318-326 (in Chinese with English abstract)

Zhou, Z.G., Zhang, H.F., Liu, H.L., Liu, C.F., Liu, W.C., 2009. Zircon U-Pb dating of basic intrusions in Siziwangqi area of middle Inner Mongolia, China. Acta Petrologica Sinica 25(6), 1519-1528 (in Chinese with English abstract).

Zhou, Z.G., Gu, Y.C., Liu, C.F., Yu, Y.S., Zhang, B., Tian, Z.J., He, F.B., Wang, B.R., 2010. Discovery of Early-Middle Permian cathaysian flora in Manduhubaolage area, Dong Ujimqin Qi, Inner Mongolia, China and its geological significance. Geological Bulletin of China 28(12), 21-25 (in Chinese with English abstract). 
Figure 1. a. Tectonic sketch map of Northeastern China, modified after Wu et al., (2007), Xu et al., (2013) and Tomurtogoo, (2013). b. Geological map of southwestern margin of Airgin Sum-Xilinhot-Xing'an Block from Erenhot to Dongwuqi, after IMBGMR, (1991).

Figure 2. Stratigraphic column of Ordovician to Devonian strata from Chaganaobao, Narenbaolige and West Ujimqin area, showing lithology and sample sites.

Scale of Fig. 3a

Figure 3. a-e, Field photographs and photomicrographs of dated strata, with number, age and lithology at the top; f, basal conglomerate of Lower-Middle Devonian Niqiuhe Formation at the Chagenaobao area.

Figure 4. Cathodoluminescence (CL) images of selected detrital zircons from each sample. The circles represent $\mathrm{U}-\mathrm{Pb}$ analytical sites, with ages presented below.

Figure 5. U-Pb concordia and probability diagrams of zircon ages from Ordovician to Devonian sandstone and siltstone of this study. The inset figures within each $\mathrm{U}-\mathrm{Pb}$ Concordia diagram show zircon grains with ages of 400-600 Ma.

Figure 6. Comparison of probability plots for the data from southwestern Xing'an Block (a; this study), middle Xing'an Block (b; Li et al., 2011), northeastern Xing'an 
Block (c; Han et al., 2011), Mongolia (d; Rojas-Agramonte et al., 2011) and Hunshandake Block (e; Xu et al., 2013).

Figure 7. Schematic geodynamic evolutionary model of the northwestern margin of Airgin Sum-Xilinhot-Xing'an Block and Songliao-Hunshandaka Block. a. The collision between Erguna-Kerulen Block and Airgin Sum-Xilinhot-Xing'an Block occurred before the Middle Cambrian, followed by 510-485 Ma post-collisional granite. This new formed block separated from the Songliao-Hunshandake Block by the Paleo-Asian Ocean. b, Started from the Late Cambrian, The Paleo-Asian Ocean subducted beneath the Airgin Sum-Xilinhot-Xing'an Block from the Late Cambrian to the Middle Silurian, producing Baolidao Arc at its southern margin. Meanwhile, on the new formed Erguna-Xing'an Block, Ordovician-Silurian magmatic rocks intruded and extensional sedimentary basins developed. The contemporary Baolidao arc magmatic rocks and post-orogenic rocks provided provenance for the sedimentary basins. c. Late Silurian Tuvaella fauna bearing sediments widespread on the Erguna-Xing'an Block, representing the stabilization of this welded block. The Baolidao arc magmatism might ceased during this period. d. During the Early-Middle Devonian, this belt underwent different evolution from west to east. To the west, the basal conglomerate represents the closure of this basin and cease of northward subduction. While to the east, shallow marine sediments still exists until the Late Devonian, indicating 
eastward successive closure of the sedimentary basin. As the pre-Late Devonian collision between Songliao-Hunshandake Block and Airgin Sum-Xilinhot-Xing'an Block, the Upper Devonian molassic sediments unconformbly overlies the ophiolitic mélange (Xu et al., 2013). Meanwhile, the marine basins on the Erguna-Xing'an Block were closed as no Late Devonian to the west and Late Devonian continental facies sediments to the east. 


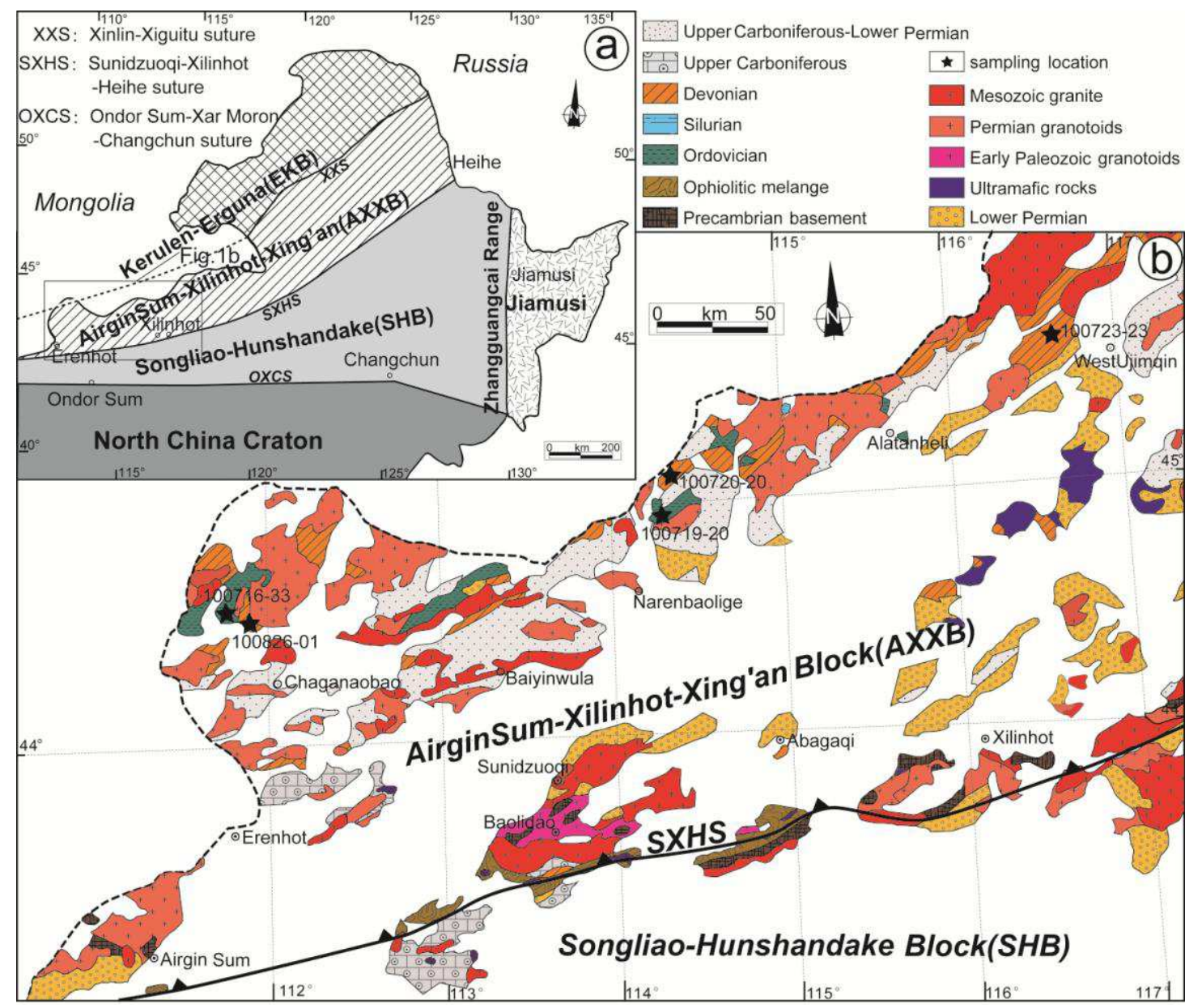

Fig. 1 a. Tectonic sketch map of Northeastern China, modified after Wu et al., (2007), Xu et al., (2013) and Tomurtogoo, (2013). b. Geological map of southwestern margin of Airgin Sum-Xilinhot-Xing'an Block from Erenhot to Dongwuqi, after IMBGMR, (1991). 


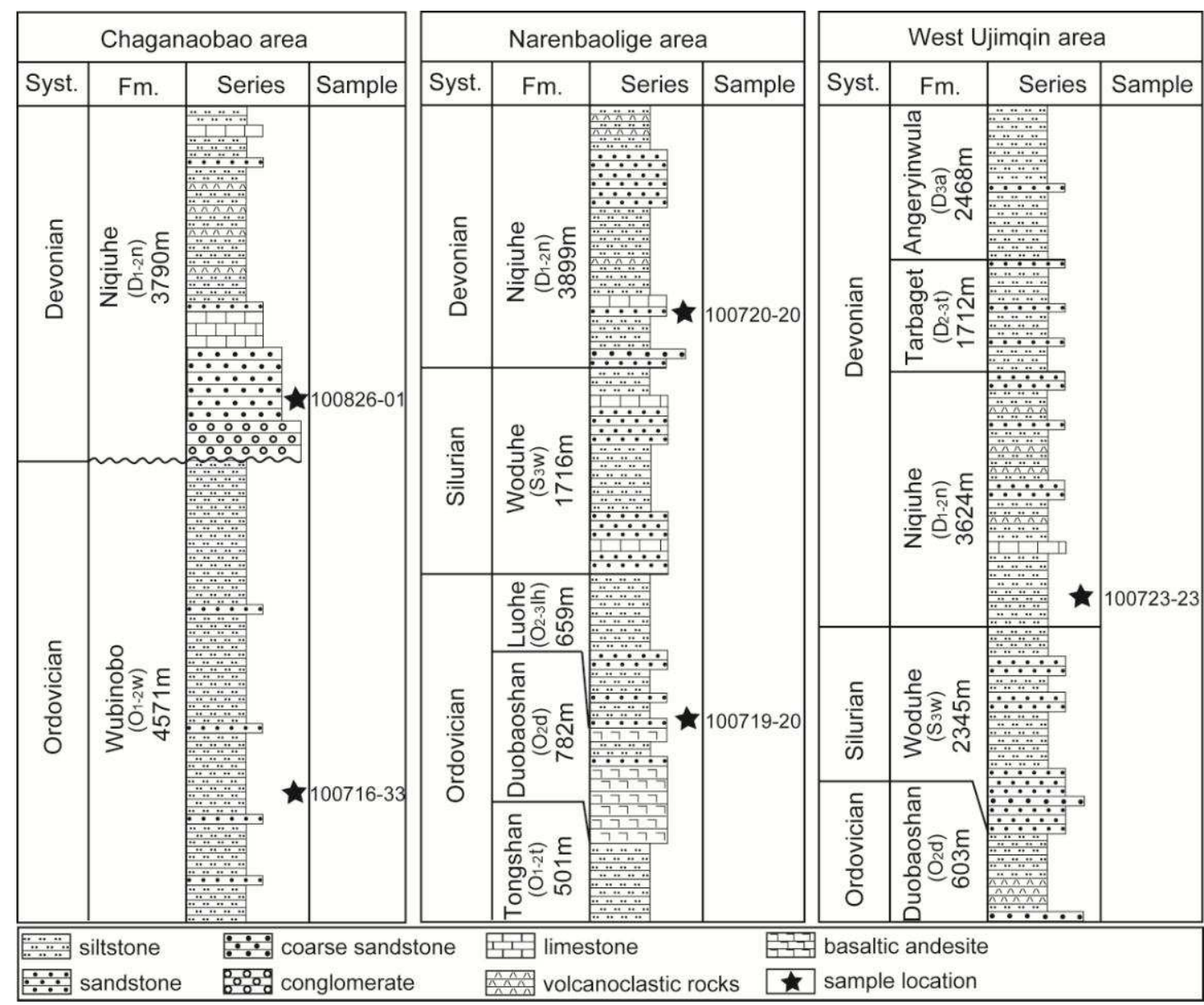

Fig. 2 Stratigraphic column of Ordovician to Devonian strata from Chaganaobao, Narenbaolige and West Ujimqin area, showing lithology and sample sites. 

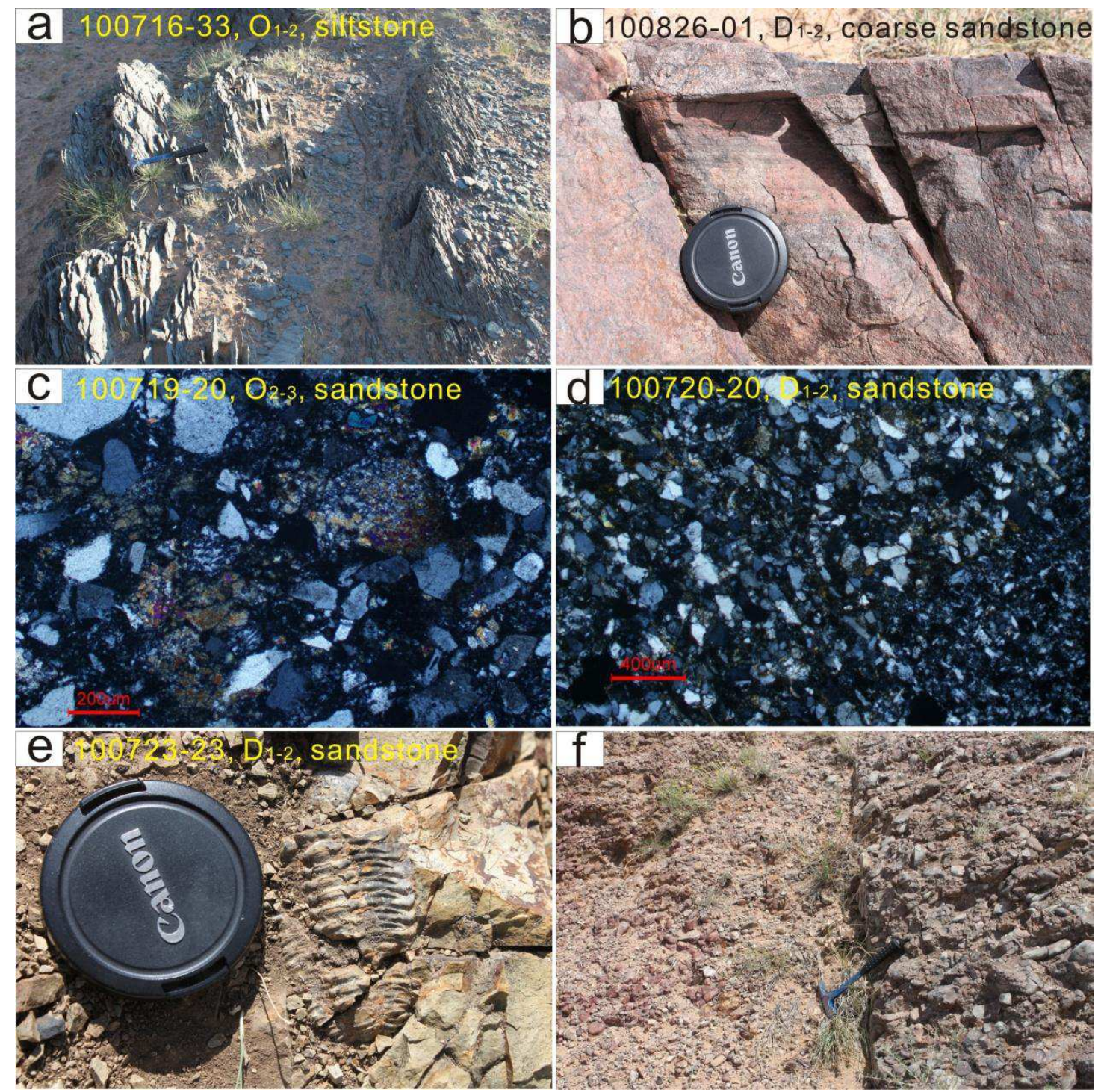

Fig. 3. a-e, Field photographs and photomicrographs of dated strata, with number, age and lithology at the top. $f$, basal conglomerate of Lower-Middle Devonian Niqiuhe Formation at Chagenaobao area. 

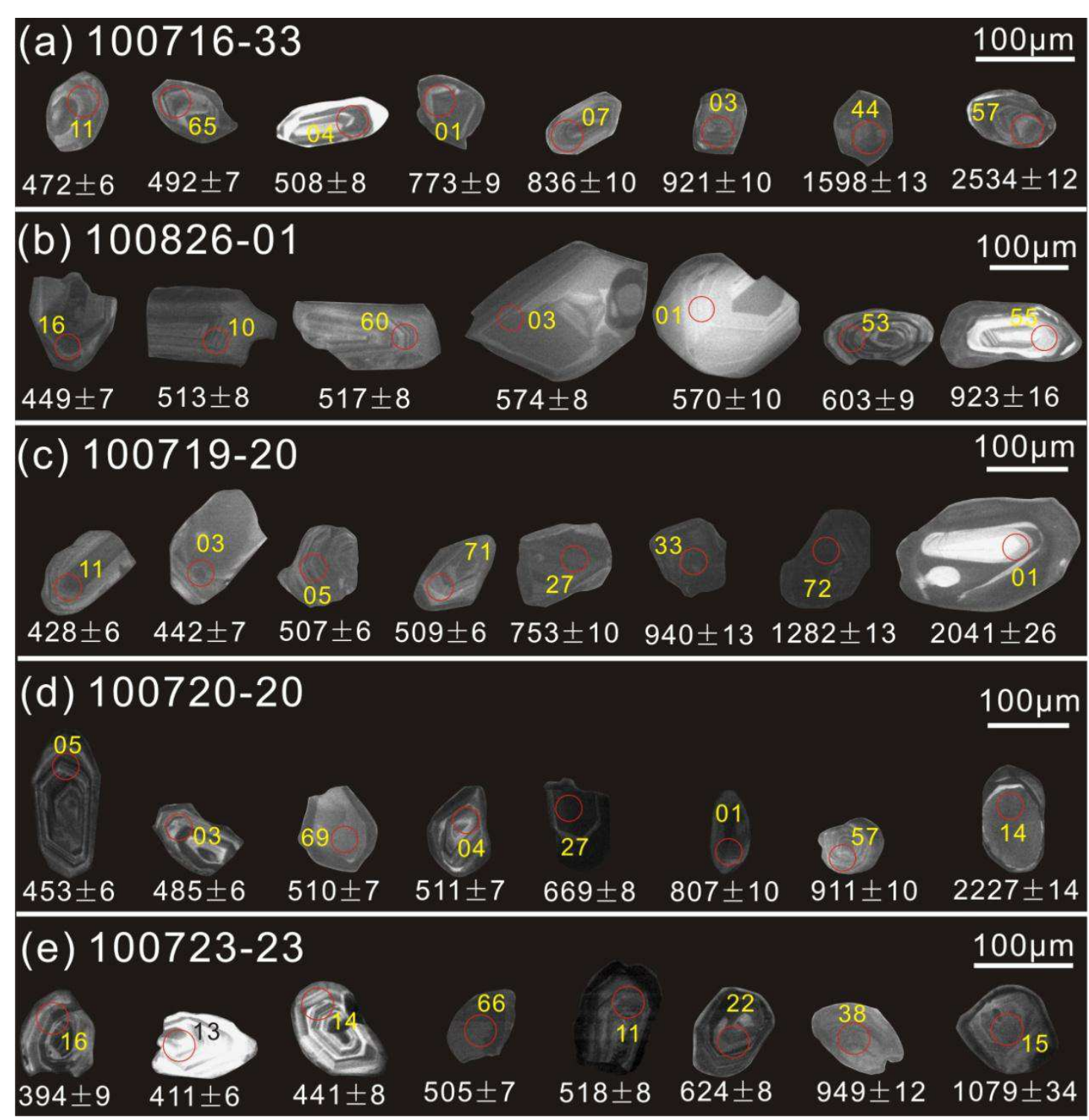

Fig. 4. Cathodoluminescence $(\mathrm{CL})$ images of selected detrital zircons from each sample. The circles represent $\mathrm{U}-\mathrm{Pb}$ analytical sites, with ages presented below. 

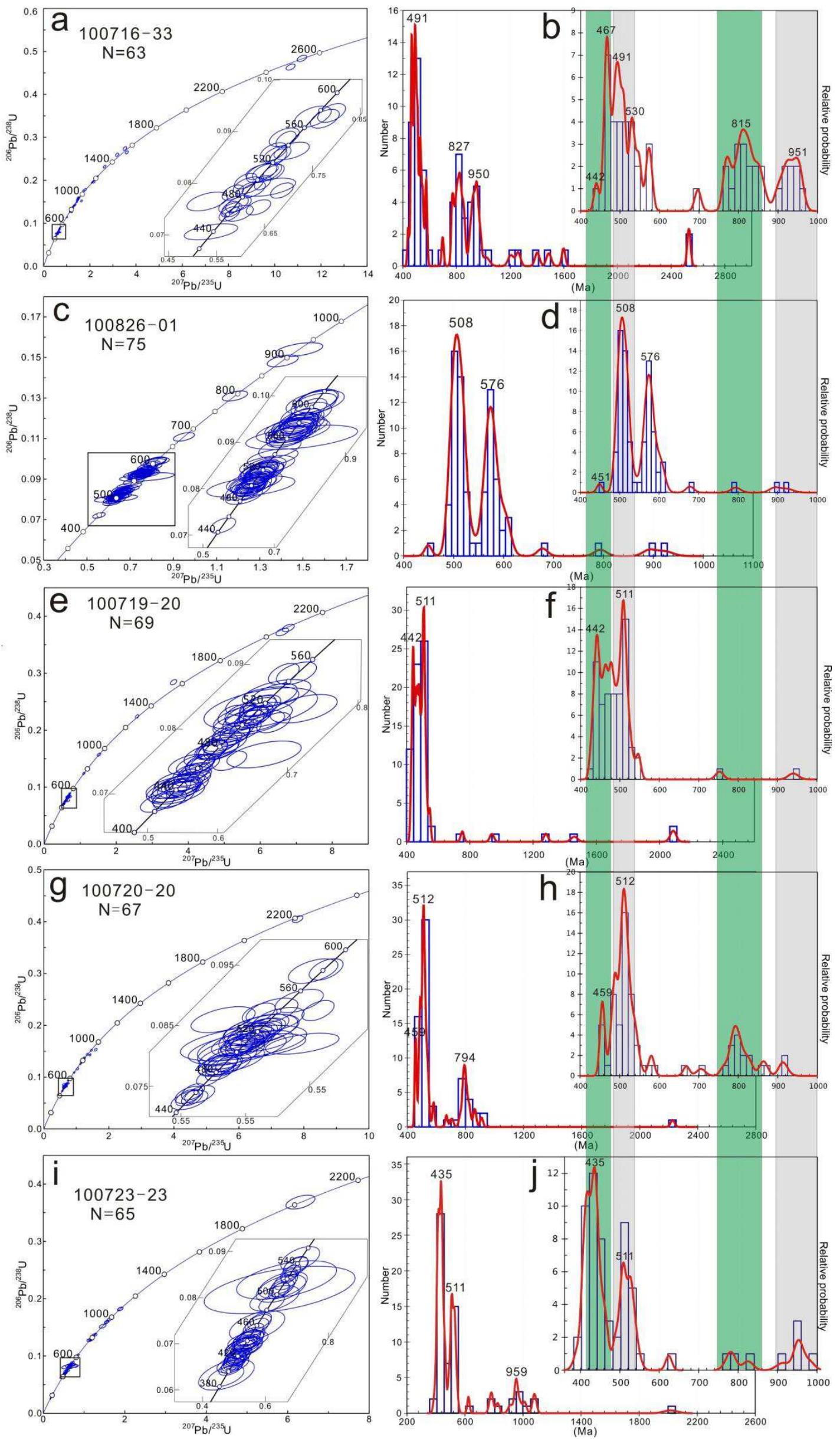
Fig. 5. U-Pb concordia and probability diagrams diagrams of zircon ages from Ordovician to Devonian sandstone and siltstone of this study. The inset figures within each U-Pb Concordia diagram show zircon grains with ages of 400-600 Ma. 


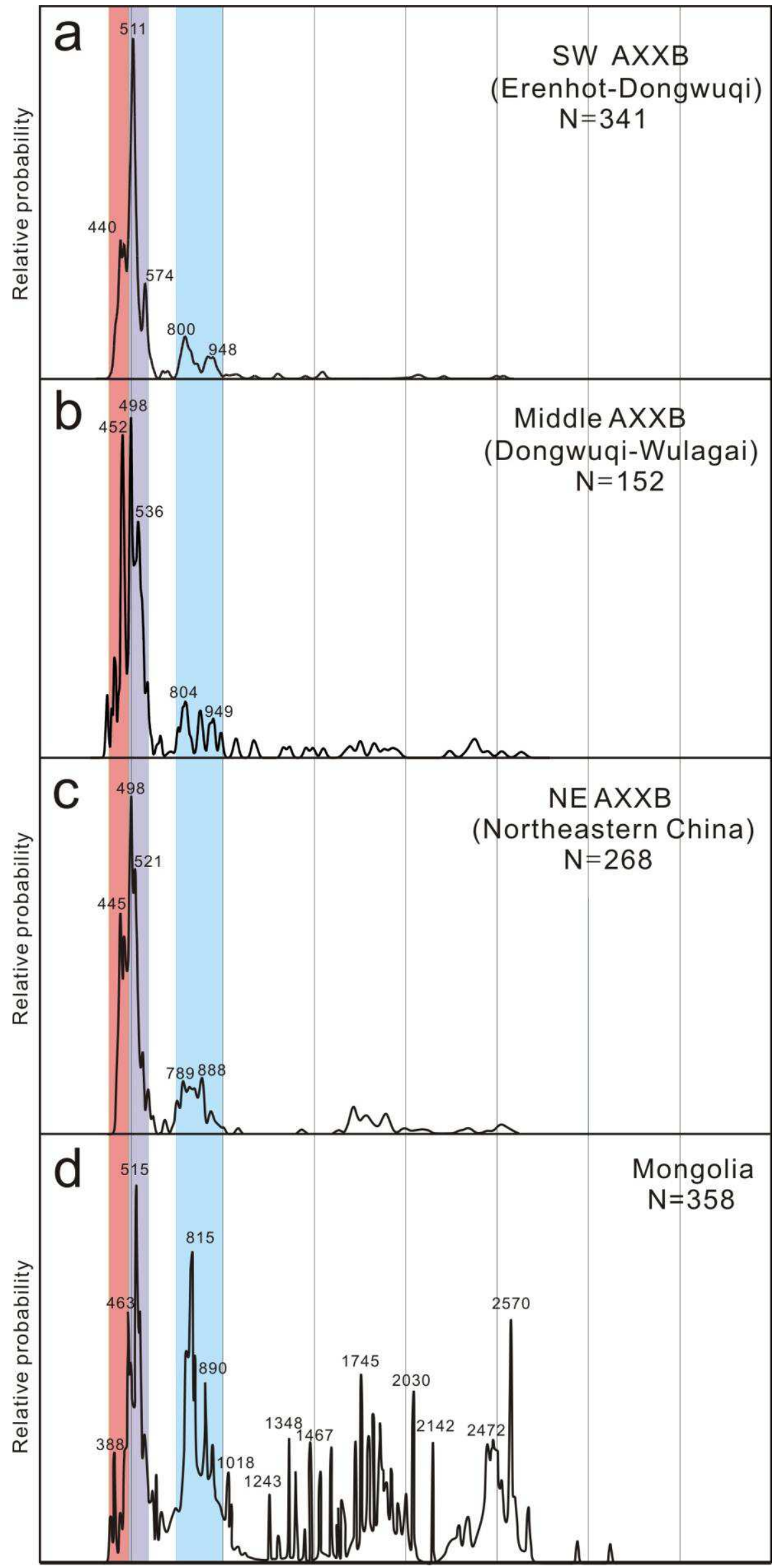


Fig. 6. Comparison of probability plots for the data from southwestern Airgin Sum-Xilinhot-Xing'an Block (a; this study), middle Airgin Sum-Xilinhot-Xing'an Block (b; Li et al., 2011), northeastern Airgin Sum-Xilinhot-Xing'an Block (c; Han et al., 2011) and Mongolia (d; Rojas-Agramonte et al., 2011). 
a. Cambrian

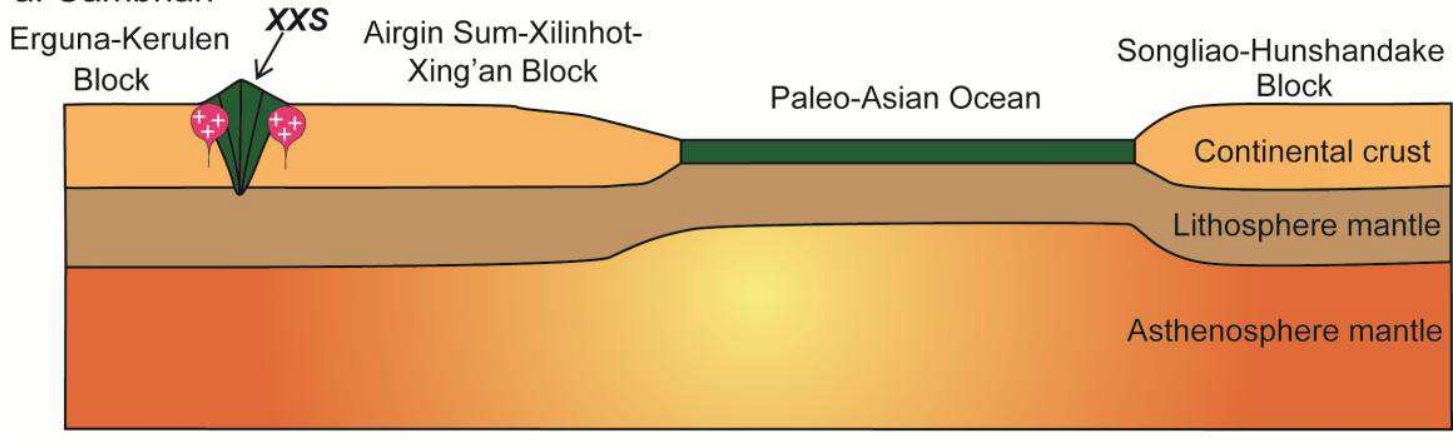

\section{b. Ordovician}

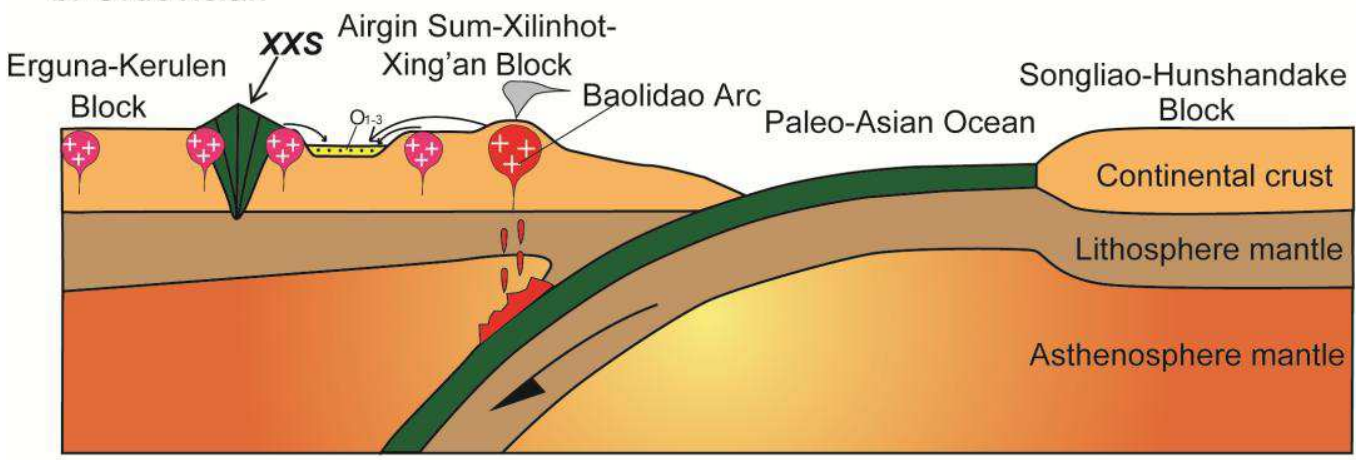

c. Late Silurian

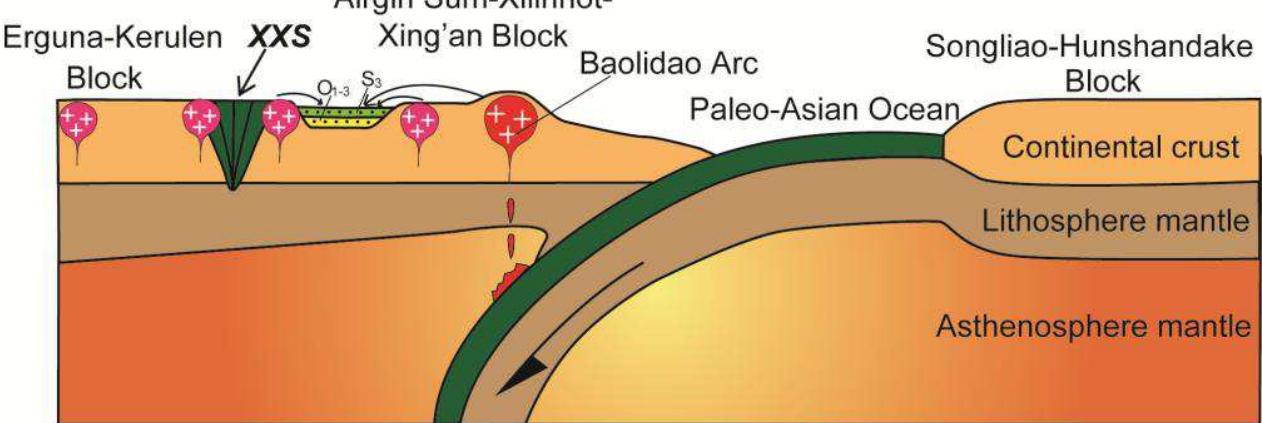

d. Early-Late Devonian
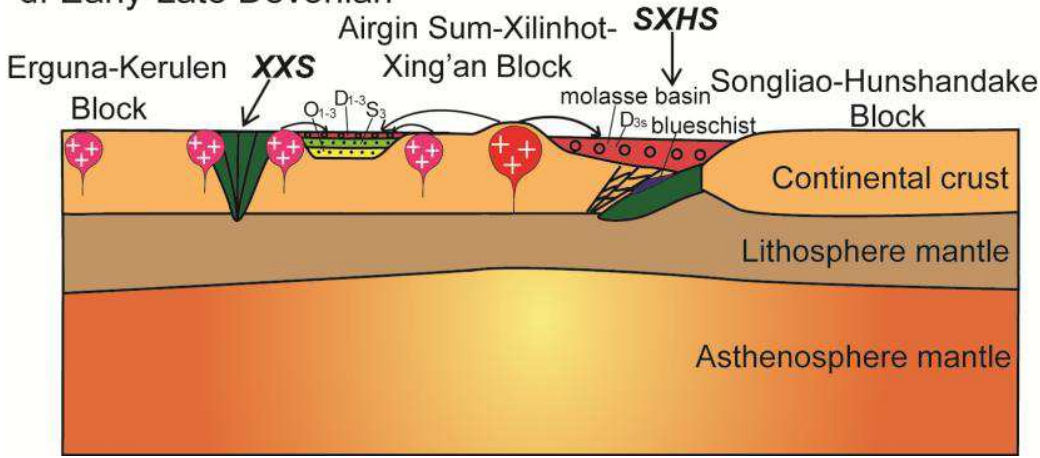

Fig. 7. Schematic geodynamic evolutionary model of the northwestern margin of Airgin Sum-Xilinhot-Xing'an Block and Songliao-Hunshandaka Block. a. The collision between Erguna-Kerulen Block and Airgin Sum-Xilinhot-Xing'an Block occurred before the Late Cambrian, followed by Late Cambrian granitic and mafic intrusions on the both sides of the Xinlin-Xiguitu suture zone (XXS). This new formed block separated from the Songliao-Hunshandake Block by the Paleo-Asian Ocean. b, Started from the Late Cambrian, The Paleo-Asian Ocean subducted beneath the Airgin Sum-Xilinhot-Xing'an Block from the Late Cambrian to the Middle Silurian, 
producing Baolidao Arc at its southern margin. Meanwhile, on the new formed Erguna-Xing'an Block, Ordovician-Silurian magmatic rocks intruded and extensional sedimentary basins developed. The contemporary Baolidao arc magmatic rocks and post-orogenic intrusions provided provenance for the sedimentary basins. c. Late Silurian Tuvaella fauna bearing sediments widespread on the Erguna-Xing'an Block, representing the stabilization of this welded block. The Baolidao arc magmatism might ceased during this period. $d$. During the Early-Middle Devonian, this belt underwent different evolution from west to east. To the west, the basal conglomerate represents the closure of this basin and cease of northward subduction. While to the east, shallow marine sediments still exists until the Late Devonian, indicating eastward successive closure of the sedimentary basin. As the pre-Late Devonian collision between Songliao-Hunshandake Block and Airgin Sum-Xilinhot-Xing'an Block along the Sunidzuoqi-Xilinhot-Heihe suture zone (SXHS), the Upper Devonian molassic sediments unconformbly overlies the ophiolitic mélange (Xu et al., 2013). Meanwhile, the marine basins on the Erguna-Xing'an Block were closed as no Late Devonian to the west and Late Devonian continental facies sediments to the east. 